\title{
Resistance to pre-harvest aflatoxin contamination in ICRISAT's groundnut mini core collection
}

\author{
F. Waliyar • K. Vijay Krishna Kumar • M. Diallo • \\ A. Traore $\cdot$ U. N. Mangala $\cdot$ H. D. Upadhyaya • \\ H. Sudini
}

Accepted: 4 February 2016/Published online: 10 February 2016

(C) Koninklijke Nederlandse Planteziektenkundige Vereniging 2016 period of four years from 2008 to 2011 indicated that the mean toxin levels ranged from 0.9 to $10.3 \mu \mathrm{g} \mathrm{kg}^{-1}$. In total, 31 accessions had less aflatoxin accumulation than the resistant check, 55-437. The seven best accessions, ICGs 13,603, 1415, 14,630, 3584, 5195, 6703 and 6888, over six years (2008-2013) consistently accumulated very low levels of aflatoxin $\left(<4 \mu \mathrm{g} \mathrm{kg}^{-1}\right)$. These seven accessions could be potential sources for understanding the resistant mechanisms and can be further used in developing resistant cultivars or introgressing resistance in popular released varieties.

Keywords Groundnut · Aflatoxins · Aspergillus flavus · Mini core collection $\cdot$ Resistance

\section{Introduction}

Groundnut (Peanut; Arachis hypogaea L.), an important food legume grown worldwide, is considered a rich source of protein for both humans and animals. However, aflatoxin contamination induced by Aspergillus flavus and A. parasiticus is a major constraint to the global trade of groundnut. According to World Health Organization (WHO), staple foods in developing countries are often contaminated with aflatoxins which result in health-related hazards (e.g., aflatoxicosis) when consumed. Important health implications of aflatoxin poisoning include immuno-suppression, impaired growth, various cancers, and death depending on the type, period and amount of exposure (Williams et al. 2004; Wagacha and Muthomi 2008).

M. Diallo

International Crops Research Institute for the Semi-Arid Tropics (ICRISAT), Niamey, Niger 
These health problems are more severe in African communities due to exposure to aflatoxins throughout their lives (Williams et al. 2004; Wild and Gong 2010). There have been increasing reports of aflatoxin contamination in freshly harvested groundnuts in several countries of sub-Saharan Africa. Recently, 22-54\% of groundnut samples collected during 2009 and 2010 from different groundnut growing districts in Mali showed $>20 \mu \mathrm{g} \mathrm{kg}^{-1}$ of aflatoxins (Waliyar et al. 2015a). This contamination renders the commodity unfit for human consumption and unacceptable for trade in high-value markets. In Malawi, one of the important groundnut growing countries in East and Southern Africa, $21 \%$ and $8 \%$ of groundnut samples were found to contain aflatoxin levels of $>20 \mu \mathrm{g} \mathrm{kg}^{-1}$ during 2008 and 2009, respectively (Monyo et al. 2012). About $78 \%$ of aflatoxin contaminated raw groundnut samples were reported in Botswana with aflatoxin concentrations ranging from 12 to $329 \mu \mathrm{g} \mathrm{kg}^{-1}$ (Barro et al. 2002).

Aflatoxin control and prevention strategies mainly include stopping the infection process of $A$. flavus by host-plant resistance/tolerance, biological control, managing environmental factors, pre-harvest and postharvest crop management practices (Waliyar et al. 2008, 2015b; Hell and Mutegi 2011). Breeding the plant for resistance to seed infection and/or aflatoxin contamination is one of the economically feasible options in managing both pre-and post-harvest aflatoxin contamination in groundnut. Resistance breeding to groundnut aflatoxin contamination can be achieved by imparting resistance to pre-harvest seed infection, in vitro seed colonization (IVSC) by A. flavus and aflatoxin production (Nigam et al. 2009). However, independently inherited nature of these three types of resistance coupled with high $\mathrm{G} \times \mathrm{E}$ interaction makes it difficult to improve the host plant resistance in groundnut (Utomo et al. 1990; Upadhyaya et al. 1997; Nigam et al. 2009). Despite the constraints, many researchers have focused on the identification of new sources of resistances for all these three types. For example, the germplasm accession lines, PI 337394 F, PI 337409 and $\mathrm{J} 11$, were confirmed to be resistant to IVSC by A. flavus (Zambettakis et al. 1981; Kisyombe et al. 1985). Additional sources such as Ah 78,223, U 4-47-7, Var 27, Faizpur and Monir 240-30 were also identified as being resistant to IVSC by A. flavus (Mehan 1989). Due to the lack of resistance of IVSC resistant genotypes under field conditions, the research focus has been shifted to identifying resistant sources to pre-harvest infection and subsequent aflatoxin contamination. Later attempts have identified potentially resistant groundnut genotypes for pre-harvest aflatoxin contamination (Waliyar et al. 1994; Anderson et al. 1995; Upadhyaya et al. 2004). Three groundnut genotypes such as ICGV 87084, ICGV 87094 and ICGV 87110 were identified to be resistant to A. flavus and aflatoxin contamination as evaluated in Niger, Senegal and Burkina Faso in West Africa (Waliyar et al. 1994). Further improved groundnut germplasm lines such as ICGV 91278, ICGV 91283 and ICGV 91284 were registered as resistant to $A$. flavus seed infection (Upadhyaya et al. 2001). In China, a cultivar "Zhonghua 6" has been reported to be resistant to aflatoxin formation and is being widely cultivated in central China (Liao et al. 2009). However, the value of a resistant source depends on the level and stability of its resistance in view of the high $\mathrm{G} \times \mathrm{E}$ interaction for this important trait (Upadhyaya et al. 2002a). On the other hand, variability in the toxigenicity of $A$. flavus populations poses threat to the performance of resistant genotypes under varied climatic conditions and multiple environments.

Plant genetic resources are widely used in breeding programs for imparting resistance to various pests and diseases (Knauft and Gorbet 1989; Upadhyaya et al. 2010). Over the years, around 3000 groundnut germplasm accessions including wild Arachis germplasm accessions were evaluated for resistance to aflatoxin contamination (Thakur et al. 2000; Nigam et al. 2009; Holbrook et al. 2009). However, considering the number of groundnut germplasm accessions available in gene banks (around 15, 000), many precious germplasm accessions might not get evaluated for this important trait. It is very difficult to screen such a huge collection under field conditions. Hence, researchers have developed "core" (Holbrook et al. 1993) and "mini core" collections (Upadhyaya et al. 2002b) of groundnut that represent the genetic variability of the entire collection and serves as handy germplasm sets for evaluating important biotic and abiotic stresses. Selection of resistant sources through systematic screening of mini core collection accessions is in practice for infusing genetic diversity (Upadhyaya et al. 2010). Although there are some reports on the screening of mini core collections for A. flavus/aflatoxin resistance (Yugandhar 2005; Kusuma et al. 2007; ICRISAT 2009), there is still lack of a detailed report on the availability of resistant sources among the ICRISAT mini core collection. 
Considering the limitations and little progress obtained using conventional breeding, enhancing host-plant resistance to aflatoxin contamination using biotechnological approaches has also been explored in groundnut (Guo et al. 2009). However, the lack of good candidates with high levels of resistance and stability in multiple environments remains an important bottleneck to the further understanding of the resistance mechanisms in groundnut by employing genomics and other cuttingedge molecular biology tools. Hence, identifying highly resistant sources to pre-harvest infection and subsequent aflatoxin contamination is important and continues to be a thrust area. Therefore, the aim of this study was to evaluate the groundnut mini core germplasm collection in an on-station experiment for several years and identify the accessions that consistently showed a good level of resistance to pre-harvest aflatoxin contamination.

\section{Materials and methods}

\section{Genotypes}

In the present study, the groundnut mini core collection consisting of 184 germplasm accessions was used (Upadhyaya et al. 2002b). These accessions were selected from 1704 entries of the core collection of groundnut representing 14,310 accessions available in the ICRISAT gene bank (Upadhyaya et al. 2003). Basically, the mini core collection was a reduced subset of the global collection of groundnut germplasm ( $1 \%$ of the entire collection). These germplasm accessions represent two subspecies (fastigiata and hypogaea) and six botanical varieties such as 37 from fastigiata, 58 from vulgaris, 85 from hypogaea, two from peruviana, and one each of aequitoriana and hirsuta. Two cultivars, 55-437 (resistant to pre-harvest aflatoxin contamination; Waliyar and Bockelee-Morvan 1989) and JL 24 (susceptible to pre-harvest aflatoxin contamination) were used as standard controls.

\section{Experimental location}

Field screening of mini core collection accessions was performed during the rainy seasons of 2008-2013 at ICRISAT-Niamey, Sadore, Niger. The normal sowing time during the study period was 3rd week of June, and the experimental plots were harvested during the $3 \mathrm{rd}$ week of October. Niger was selected for screening since it was a hot-spot location with significant pre-harvest aflatoxin contamination (Waliyar et al. 2003). The soils at Sadore were classified as sandy soils (93\% sand) (Waliyar et al. 1994; West et al. 1984). The average annual rainfall in Sadore, Niger is 562 mm (Sivakumar 1986).

\section{Preliminary field screening}

During 2008, a total of 176 mini core germplasm accessions were screened. The mini core accessions ICGs 2857, 5051, 5827, 7190, 10,036, 10,554, 14,710 and 15,419 were excluded from the screening trials due to insufficient availability of seeds. Four other accessions ICGs 13,941, 13,942, 2738 and 156 were also included. In 2009, a total of 166 accessions comprising $162 \mathrm{mini}$ core accessions and four other accessions, ICGs 13,941, 13,942, 2738 and 156 tested during 2008 were also screened. The mini core germplasm accessions, ICGs 2857, 5051, 5827, 7190, 10,036, 10,554, 14,710, $15,419,6646,6766,6667,2381,11,088,6022$, $12,625,4746,12,000,9905,1668,6993,6913$ and 11,426 were not included during this screening experiment. Two resistant (55-347 and J 11) and two susceptible checks (Fleur 11 and JL 24) for pre-harvest aflatoxin contamination were used during 2008 and 2009. The experiments were laid out in a Randomized Complete Block Design (RCBD) with three replications. The plot size during 2008 was $4.5 \mathrm{~m}^{2}$ $(1.5 \mathrm{~m} \times 3.0 \mathrm{~m})$ of three rows, each measuring $3 \mathrm{~m}$ with a gap of $50 \mathrm{~cm}$ between rows and $10 \mathrm{~cm}$ between seeds. During 2009, the plot size was $8 \mathrm{~m}^{2}$ with four rows of $4 \mathrm{~m}$ length, with a similar arrangement of accessions.

A total of 34 accessions were screened during 2010 and 2011. Of these, 25 promising accessions were from 2008 and 2009 field experiments with a mean aflatoxin content of $<7 \mu \mathrm{g} \mathrm{kg}^{-1}$. The accession ICG 6402 with mean aflatoxin content of $4.8 \mathrm{\mu g} \mathrm{kg}^{-1}$ during 2008 and 2009 studies was not included due to insufficient seed. Further, nine promising accessions (ICGs 11,515, 12,988, 4543, 4670, 532, 81, 9157, 3775 and 13,603) from our earlier field studies (data not shown) were included. During both these years, 55-437 (resistant) and JL 24 (susceptible) were used as standard controls. The trials were laid out in a $6 \times 6$ Lattice design with three replications. The plot dimensions during 2010 were $8 \mathrm{~m}^{2}(2 \mathrm{~m} \times 4 \mathrm{~m})$ of four rows, each measuring $4 \mathrm{~m}$ with a gap of $50 \mathrm{~cm}$ between the rows and $10 \mathrm{~cm}$ between plants. During 2011, the trial was laid out in a 
plot size of $4.5 \mathrm{~m}^{2}$ of three rows, each measuring $3 \mathrm{~m}$ with a gap of $50 \mathrm{~cm}$ between the rows and $10 \mathrm{~cm}$ between the plants. The performance of these accessions over four years (2008-2011) was analyzed to determine the stability of resistance. The accessions ICGs 13,603 and 12,988 were also included in the performance analysis.

Final screening of selected germplasm accessions during 2012 and 2013

Seven accessions were selected and screened during 2012 and 2013. Of these, ICGs 1415, 14,630, 3584, 5195 and 6703 had a mean pre-harvest aflatoxin contamination level $<1 \mathrm{\mu g} \mathrm{kg}^{-1}$ during 2010 and 2011. The other two accessions ICGs 13,603 and ICG 6888 with $>1 \mu \mathrm{g} \mathrm{kg}^{-1}$ were also included based on our earlier studies. The standard checks, 55-437 (resistant) and JL 24 (susceptible) were also included in a $3 \times 3$ Lattice design with a plot size of $6 \mathrm{~m}^{2}$ with three replications.

In all the experimental plots year-wise, care was taken to ensure uniform depth of planting. Standard agronomic and cultural practices were followed during all the years of experimentation. Plot-wise harvesting of accessions was carried out at optimum maturity.

Data collection

Weather data for the years 2004 to 2013 were recorded daily inclusive of the crop growth periods by a nearby meteorological station from the experimental Fields. maximum and minimum air temperatures and precipitation were recorded for the study period. The mean minimum and maximum temperatures in Celsius over the experimental years ranged from: $9.5-30.1$ to 25.4 44 (2008); $13.2-31.1$ to $26-44.5$ (2009); $12.7-31.5$ to 25.5-45.9 (2010); 13.6-31.2 to 26.6-44.2 (2011); 11.131.0 to $26.2-44.5$ (2012); and $12.1-30.7$ to $24.5-44.0$ (2013), respectively. The annual precipitation levels $(\mathrm{mm})$ during the experimental years were 480.6 (2008), 515.6 (2009), 687.5 (2010), 497.8 (2011), 649.1 (2012), and 594.4 (2013).

Pod yields were recorded by harvesting each accession (replication-wise). For harvesting, the plants were uprooted by hand and brought to the threshing floor, stripped off, and then dried prior to yield assessment. For ascertaining natural seed infection by A. flavus, the pods were shelled, and 100 seeds/plot were selected.
The seeds from each replication were surface sterilized by immersion for $3 \mathrm{~min}$ in a $0.2 \%$ aqueous solution of sodium hypochlorite. After three rinses in sterile distilled water, the seeds were transferred aseptically onto moistened filter paper in sterile Petri dishes. The Petri dishes were later incubated at room temperature $\left(25 \pm 1^{\circ} \mathrm{C}\right)$ for a maximum of 7 days and fungi growing from the seeds were identified and the per cent $A$. flavus infection was enumerated (Waliyar and BockeleeMorvan 1989). The A. flavus isolates were confirmed based on the microscopic and macroscopic characteristics using standard procedures (Raper and Fennel 1965). For aflatoxin estimation (AFB1), $500 \mathrm{~g}$ of pods were shelled and powdered, and $20 \mathrm{~g}$ was used for analysis through indirect competitive ELISA (Reddy et al. 2001). The limit of detection (LOD) of the assay was $0.01 \mu \mathrm{g} / \mathrm{kg}$.

Data analysis

The individual and pooled data for the field studies during 2008-2013 were analyzed using Residual Maximum Likelihood (REML) with the GENSTAT statistical package (version 10.1; Rothamsted Experiment Station, Herpenden, Herts AL52JQ, UK). The significance of genetic variability among accessions within treatment was assessed from the standard error of the estimate of genetic variance $\sigma^{2} \mathrm{~g}$. REML analysis was also performed to assess the effects of environment (E) and genotype-by-environment (GXE) interaction for the aflatoxin contamination trait. In this case, variation components involving " $G$ " were considered as random effects, whereas "E" and replication effects were considered as fixed. Similarly, the significance of genetic variability across treatments or the interaction effect was also assessed.

\section{Results}

Climatic conditions in sadore, Niger

The analysis of weather records for a period of 10 years (2004 to 2013) in Sadore, Niger revealed that both the maximum and minimum temperatures corresponded with the peak in April and May, respectively. However, both the temperatures were the lowest in August and January respectively. The rainfall data for the same period indicated that August had consistently 
recorded the highest rainfall, followed by the months of July and September. The data also revealed that the rainy season normally started in May and ended during October.

Statistical variances among accessions

\section{Aflatoxins}

Significant genotypic and G x E variances were observed in the pool analysis during the six years of field studies. The variance components due to genotypes $\left(\sigma^{2}\right.$ g) were quite high compared with $\mathrm{G} \times \mathrm{E}$ interaction $\left(\sigma^{2}\right.$ ge) in 2008 and 2009, indicating that the differences in aflatoxin contents were mainly contributed by the accessions in these years. Whereas in 2010-2013 and pooled season (2008-2011), the G x E variance component was quite high compared to the genotypic variance, indicating that genetic variability in aflatoxin resistance is masked by higher $\mathrm{G} x \mathrm{E}$ interaction. The Wald statistic indicated a non-significant effect of environment based on the pooled data of six environments (Table 1).

\section{Seed infection by A. flavus}

Significant genotypic variances during 2008, 2009, and 2011 and for pooled seasons (2008 to 2011) separately and $\mathrm{G} \times \mathrm{E}$ interaction in the pooled analysis were observed. In 2008 and 2009, the variance component due to genotype was high over the $\mathrm{G} x \mathrm{E}$ interaction. In 2011 and through the pooled data (2008 through 2011), a high $\mathrm{G} \times \mathrm{E}$ interaction was observed compared to genotypic variance. The Wald statistic indicated a significant effect of environment on seed infection (Table 1).

\section{Pod and haulm yields}

Significant genotypic differences were observed during 2008-2011 for both pod and haulm yields. Significant G $\mathrm{x}$ E interaction was observed in haulm yields; however, the interaction was not significant for pod yields. The Wald statistic indicated a significant difference in pod and haulm yields (Table 1).

\section{Preliminary screening of mini core germplasm accessions}

Out of the 180 accessions screened in 2008, two accessions ( $1.1 \%$ of the accessions screened) had $<4 \mu \mathrm{g} \mathrm{kg}^{-1}$ $\mathrm{AFB}_{1}$. Overall, 39 accessions $(21.7 \%)$ had aflatoxin levels up to $10 \mu \mathrm{g} \mathrm{kg}^{-1}$. In addition, 30 accessions $(16.7 \%)$ were in the range of 10.1 to $15.0 \mu \mathrm{g} \mathrm{kg}^{-1}, 13$ accessions (7.2\%) in the range of 15.1 to $20.0 \mu \mathrm{g} \mathrm{kg}^{-1}$, and seven accessions (3.9\%) were in the range of 20.1 to $30.0 \mu \mathrm{g} \mathrm{kg}^{-1}$. Thus, during 2008, 89 accessions (49.4\%) had toxin levels of $<30 \mu \mathrm{g} \mathrm{kg}^{-1}$ (Fig 1). The lowest aflatoxin content was recorded in ICG 6766 (2.6 $\left.\mu \mathrm{g} \mathrm{kg}^{-1}\right)$, followed by ICG $6402\left(3.4 \mu \mathrm{g} \mathrm{kg}^{-1}\right)$. Two accessions, ICGs 14,475 and 14,482 had very high aflatoxin levels (2913.2 to $4411.5 \mu \mathrm{g} \mathrm{kg}^{-1}$, respectively). The highest aflatoxin content was recorded in ICG $11426\left(5262.6 \mu \mathrm{g} \mathrm{kg}^{-1}\right)$. The toxin levels were up to $12.9 \mu \mathrm{g} \mathrm{kg}^{-1}$ for resistant checks, whereas they were up to $3313.5 \mu \mathrm{g} \mathrm{kg}^{-1}$ for the susceptible checks.

In 2009, 20 accessions (12\%) of the 166 accessions screened had aflatoxin levels up to $4 \mu \mathrm{g} \mathrm{kg}^{-1}$. Thirty-

Table 1 Residual maximum likelihood analysis (REML) for pre-harvest aflatoxin contamination, seed infection by Aspergillus flavus, pod and haulm yields in the mini core accessions of groundnut as evaluated during 2008 to 2013 at Sadore, Niger

\begin{tabular}{|c|c|c|c|c|c|c|c|c|c|c|}
\hline \multirow[t]{2}{*}{ Trait } & \multicolumn{7}{|l|}{$\sigma^{2} g$} & \multirow[t]{2}{*}{$\sigma^{2}$ g.e } & \multirow{2}{*}{$\begin{array}{l}\text { Wald statistic } \\
\text { (season) }\end{array}$} & \multirow[t]{2}{*}{ F prob. } \\
\hline & 2008 & 2009 & 2010 & 2011 & 2012 & 2013 & $\begin{array}{l}2008-11 \\
\text { (4 seasons) } \\
\text { pooled }\end{array}$ & & & \\
\hline Aflatoxin (ppb) & $501,606^{* *}$ & $64,914 * *$ & $4168.7 * *$ & $1038.2 * *$ & $14.2 *$ & $162.9^{*}$ & $16,780.1^{* *}$ & $15,018.5^{* *}$ & 3.53 & 0.322 \\
\hline A. flavus $(\%)$ & $400.0 * *$ & $62.9 * *$ & 13.7 & $33.0^{*}$ & 3.65 & & $35.68 * *$ & $58.5^{* *}$ & 75.29 & $<0.001$ \\
\hline Pod Yield (t/ha) & $0.25 * *$ & $0.15^{* *}$ & $0.02 *$ & $0.32 * *$ & 0.12 & 0.21 & 4.48 & 0.09 & 620.23 & $<0.001$ \\
\hline Haulm Yield (t/ha) & $1.96 * *$ & $0.91 * *$ & $0.09 *$ & $1.79 * *$ & 0.88 & 0.24 & 0.07 & $0.80 * *$ & 527.6 & $<0.001$ \\
\hline
\end{tabular}

*significant at $5 \%$ level

**significant at $1 \%$ level 
Fig. 1 Reaction of groundnut mini core accessions to preharvest aflatoxin $\mathrm{B}_{1}$ contamination during rainy seasons of 2008 and 2009 at Sadore, Niger

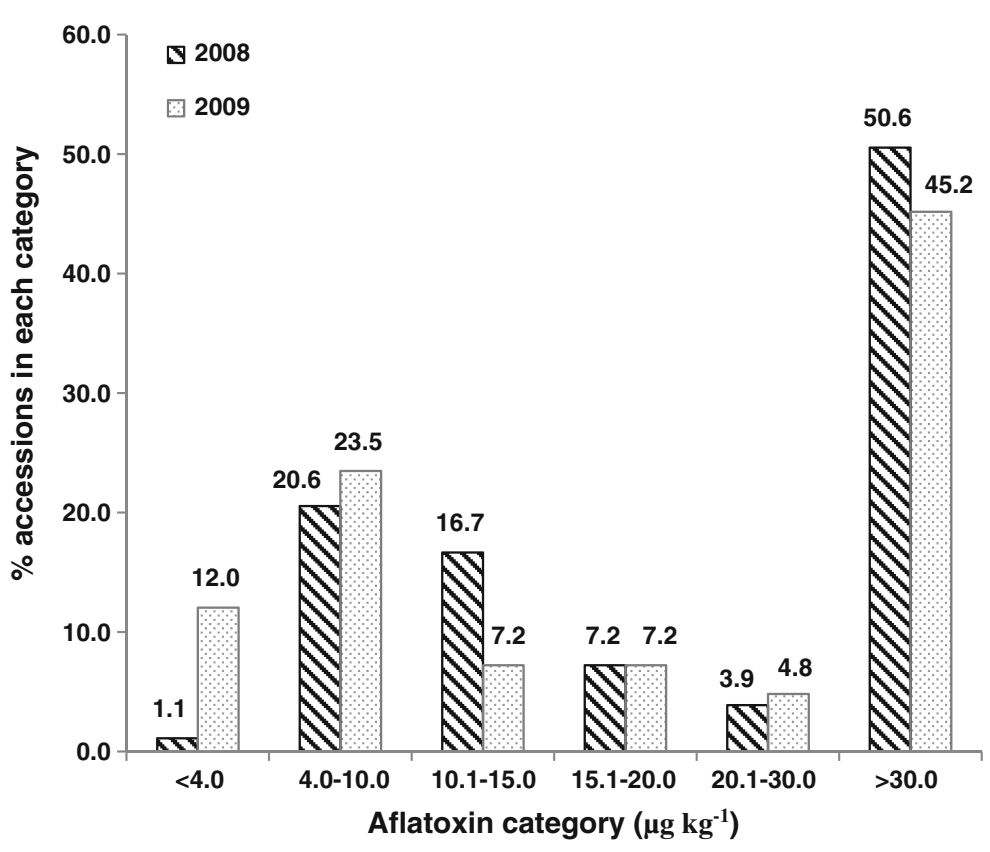

nine accessions (23.5\%) had toxin levels of 4.1 to $10.0 \mu \mathrm{g} \mathrm{kg}^{-1}, 12$ accessions $(7.2 \%)$ had 10.1 to $15 \mu \mathrm{g} \mathrm{kg}^{-1}, 12$ accessions $(7.2 \%)$ had 15.1 to $20.0 \mu \mathrm{g} \mathrm{kg}^{-1}$, and eight accessions (4.8\%) had 20.1 to $30.0 \mu \mathrm{g} \mathrm{kg}^{-1}$. Overall, 91 accessions had aflatoxin levels below $30 \mu \mathrm{g} \mathrm{kg}^{-1}$ (Fig 1). Lowest toxin levels were recorded in ICG $1415\left(1.4 \mu \mathrm{g} \mathrm{kg}^{-1}\right)$, ICG 5195 $\left(1.6 \mu \mathrm{g} \mathrm{kg}^{-1}\right)$, and ICG $14630\left(1.7 \mu \mathrm{g} \mathrm{kg}^{-1}\right)$. In 2009, the highest toxin levels were recorded in ICG 4538 (990 $\mu \mathrm{g} \mathrm{kg}^{-1}$ ), followed by ICG 9315 $\left(988.3 \mu \mathrm{g} \mathrm{kg}^{-1}\right)$. The toxin levels in the resistant checks were up to $7.6 \mu \mathrm{g} \mathrm{kg}^{-1}$, whereas they were up to $1048.3 \mu \mathrm{g} \mathrm{kg}^{-1}$ in the susceptible checks.

The average performance of 166 accessions in resisting pre-harvest aflatoxin contamination for 2008 and 2009 are shown in Table 2. Four accessions had aflatoxins up to $4 \mu \mathrm{g} \mathrm{kg}^{-1}$. A total of 46 accessions had aflatoxins level in the range of 4.1 to $10.0 \mu \mathrm{g} \mathrm{kg}^{-1}, 16$ accessions had 10.1 to $15.0 \mu \mathrm{g} \mathrm{kg}^{-1}$, and nine accessions had aflatoxins in the range of 15.1 to $20.0 \mu \mathrm{g} \mathrm{kg}^{-1}$. Three accessions had aflatoxin levels ranging from 1000 to $1500 \mathrm{\mu g} \mathrm{kg}^{-1}$. The highest mean aflatoxin levels above 2000 to $2500 \mu \mathrm{g} \mathrm{kg}^{-1}$ were recorded in ICG 14482 (Table 2). The mean aflatoxin levels for 2008 and 2009 indicated that 25 accessions had aflatoxin $B_{1}$ up to $7 \mu \mathrm{g} \mathrm{kg}^{-1}$. Overall, the mean toxin contents ranged from 2.9 to $2278.9 \mu \mathrm{g} \mathrm{kg}^{-1}$.
In 2010, aflatoxin accumulation in 34 accessions ranged from 0.06 to $12.81 \mu \mathrm{g} \mathrm{kg}^{-1}$. In 2011, the aflatoxin content in the same 34 accessions was in the range of 0.14 to $14.71 \mathrm{\mu g} \mathrm{kg}^{-1}$. The mean aflatoxin level of eight accessions was up to $1 \mu \mathrm{g} \mathrm{kg}^{-1}$ for 2010 and 2011 and the mean toxin level of seven accessions ranged from 1.1 to $2.0 \mu \mathrm{g} \mathrm{kg}^{-1}$ (Table 3). Aflatoxin levels in 55-437 (resistant check) and JL 24 (susceptible check) were 2.24 and $289.41 \mu \mathrm{g} \mathrm{kg}^{-1}$, respectively. The details of accessions with their respective range of mean aflatoxin levels in 2010 and 2011 are provided in Table 3.

The performances of 34 accessions resistant to preharvest aflatoxin contamination over four years (20082011) are depicted in Table 4. The mean toxin levels ranged from 0.98 (ICG 13603) to $10.34 \mu \mathrm{g} \mathrm{kg}^{-1}$ (ICG 12988) (Table 4). The other accessions with aflatoxin levels below $2 \mu \mathrm{g} \mathrm{kg}^{-1}$ include ICGs 14,630, 1415, $5195,3584,8490$, and 6703 . The toxin content of the resistant check (55-437) was $5.7 \mu \mathrm{g} \mathrm{kg}^{-1}$. Out of the 34 accessions, 31 had aflatoxin levels below that of the resistant check (55-437). The susceptible check (JL 24) recorded the highest toxin content of $861.9 \mu \mathrm{g} \mathrm{kg}^{-1}$. Pod yields ranged from 0.86 (ICG 513) to $1.91 \mathrm{t} \mathrm{ha}^{-1}$ (ICG 3584). The pod yields in resistant check (55-437) and susceptible checks (JL 24) were $1.68 \mathrm{t} \mathrm{ha}^{-1}$ and $1.37 \mathrm{t} \mathrm{ha}^{-1}$, respectively. Haulm yields ranged from 2.71 to $4.38 \mathrm{t} \mathrm{ha}^{-1}$ among the accessions (Table 4). 
Table 2 Reaction of groundnut mini core accessions to pre-harvest aflatoxin contamination during 2008 and 2009 at Sadore, Niger

\begin{tabular}{|c|c|c|}
\hline $\begin{array}{l}\text { Aflatoxin } \\
\text { levels }\left(\mu \mathrm{g} \mathrm{kg}^{-1}\right)\end{array}$ & $\begin{array}{l}\text { No. of } \\
\text { accessions }\end{array}$ & Details \\
\hline $0.0-4.0$ & 4 & ICGs $5195,14,630,1415,6703$ \\
\hline $4.1-10.0$ & 46 & $\begin{array}{c}\text { ICGs } 3584,6407,6263,8490,5663,6402,862,7153,513,6201,4750,7181,12,697,6888,721,1711, \\
1142,8285,332,6654,6375,9666,15,309,4543,5609,11,515,4670,12,988,532,13,858,13,941, \\
11,322,11,457,14,106,81,875,11,249,9157,9249,3775,14,118,163,2106,3053,13,099,10,890\end{array}$ \\
\hline $10.1-15.0$ & 16 & ICGs $14,523,3027,15,287,13,603,111,11,687,156,12,370,1519,76,334,1137,3421,2019,2879,5779$ \\
\hline $15.1-20.0$ & 9 & ICGs $36,11,144,4729,8083,1973,9809,13,942,297,12,672$ \\
\hline $20.1-30.0$ & 14 & ICGs $2773,1274,11,109,115,13,723,15,190,12,921,15,042,2772,7969,9507,9842,14,127,4998$ \\
\hline $30.1-100$ & 22 & $\begin{array}{l}\text { ICGs } 118,3343,11,862,5745,9777,442,188,13,856,11,651,8567,10,092,3746,9961,13,491,10,474 \text {, } \\
\quad 8760,11,855,3681,14,705,3240,13,787,4412\end{array}$ \\
\hline $100.1-500$ & 34 & $\begin{array}{l}\text { ICGs } 1399,434,6057,2738,5327,5475,928,14,008,5494,4955,7243,14,466,10,384,5016,12,189, \\
\quad 4156,4684,5891,4911,5236,6813,4527,4598,4343,2777,4389,5662,11,219,8106,13,982,7906, \\
\quad 7000,14,985,7963\end{array}$ \\
\hline $500.1-1000$ & 16 & $\begin{array}{l}\text { ICGs } 12,682,9037,3102,10,479,10,566,12,276,8517,5286,3992,6892,10,185,2511,397,3673,2925 \text {, } \\
\quad 9315\end{array}$ \\
\hline $1000.1-1500$ & 3 & ICGs 4538, 5221, 9418 \\
\hline $1500.1-2000$ & 1 & ICG 14475 \\
\hline $2000.1-2500$ & 1 & ICG 14482 \\
\hline
\end{tabular}

Aflatoxin levels are estimated at harvest using ELISA

Aflatoxin values are means of 2008 and 2009 data

Final screening of selected mini core accessions in 2012 and 2013

In 2012, all the seven elite accessions (ICGs 1415, $14,630,3584,5195,6703,6888$ and 13,603) had aflatoxins below $1 \mu \mathrm{g} \mathrm{kg}^{-1}$. Toxin content was the least in ICG 13603 and ICG $14630\left(0 \mu \mathrm{g} \mathrm{kg}^{-1}\right)$, whereas it was the highest in ICG $6888\left(0.86 \mu \mathrm{g} \mathrm{kg}^{-1}\right)$. The resistant check (55-437) recorded $1.58 \mu \mathrm{g} \mathrm{kg}^{-1}$, whereas the susceptible check (JL 24) recorded about $11.68 \mu \mathrm{g} \mathrm{kg}^{-1}$. The mean A. flavus infection of seeds for these accessions ranged from $1.30 \%$ (ICG 1415) to $2.7 \%$ (ICG 6888) (Table 5). The pod yields ranged from 1.40 (ICG 14630) to $2.22 \mathrm{t} \mathrm{ha}^{-1}$ (ICG 1415). The resistant check has a pod yield of $1.94 \mathrm{t} \mathrm{ha}^{-1}$, whereas the susceptible check recorded $2.16 \mathrm{t} \mathrm{ha}^{-1}$.

In 2013, three accessions (ICGs 6888, 1415 and $13,603)$ had aflatoxins up to $1 \mu \mathrm{g} \mathrm{kg}^{-1}$, and four accessions (ICGs 3584, 5195, 6703 and 14,630) had aflatoxins below $3 \mu \mathrm{g} \mathrm{kg}^{-1}$ (Table 6). The resistant check (55-437) had recorded aflatoxin levels of $5.5 \mu \mathrm{g} \mathrm{kg}^{-1}$, whereas susceptible check (JL 24) recorded $40 \mu \mathrm{g} \mathrm{kg}^{-1}$. The pod yields for these seven accessions ranged from 3.7 to $4.6 \mathrm{t} \mathrm{ha}^{-1}$.

Multi-year analysis of Superior accessions against pre-harvest aflatoxin contamination

Field performance of the seven best accessions (ICGs $1415,14,630,3584,5195,6703,6888$ and 13,603) for
Table 3 Reaction of selected groundnut mini core accessions to pre-harvest aflatoxin contamination during 2010 and 2011 at Sadore, Niger

Aflatoxin levels are estimated at harvest using ELISA

Aflatoxin values are means of 2010 and 2011 data

\begin{tabular}{lll}
\hline $\begin{array}{l}\text { Aflatoxin levels } \\
\left(\mu \mathrm{kg}^{-1}\right)\end{array}$ & $\begin{array}{l}\text { No. of } \\
\text { accessions }\end{array}$ & Details \\
\hline $0-1.0$ & 8 & ICGs $14,630,3584,8490,1415,332,7153,5195,6703$ \\
$1.1-2.0$ & 7 & ICGs 8285, 862, 9666, 7181, 4750, 513, 6263 \\
$2.1-3.0$ & 9 & ICGs $1142,532,5663,6888,721,4543,6407,9157,4670$ \\
$3.1-4.0$ & 5 & ICGs 6201, 12,697, 6654, 1711, 11,515 \\
$4.1-5.0$ & 2 & ICGs 81,3775 \\
$>5.0$ & 3 & ICGs 6375, 12,988, 13,603 \\
\hline
\end{tabular}


Table 4 Evaluation of groundnut mini core accessions for their resistance to pre-harvest aflatoxin contamination during the rainy seasons of 2008, 2009, 2010 and 2011 at Sadore, Niger
55-437 was the resistant check and JL 24 was the susceptible check

Values are means of four years with three replications/treatment/ year

*significant at $1 \%$ level

\begin{tabular}{|c|c|c|c|}
\hline Genotype & Aflatoxin (ppb)* & Pod yield (t/ha) & Haulm yield ( $\mathrm{t} / \mathrm{ha})$ \\
\hline ICG 13603 & 0.98 & 1.37 & 2.99 \\
\hline ICG 14630 & 1.43 & 1.14 & 3.65 \\
\hline ICG 1415 & 1.32 & 1.34 & 3.45 \\
\hline ICG 5195 & 1.36 & 1.17 & 3.22 \\
\hline ICG 3584 & 1.60 & 1.91 & 3.71 \\
\hline ICG 8490 & 1.93 & 1.04 & 2.92 \\
\hline ICG 6703 & 1.69 & 1.47 & 4.08 \\
\hline ICG 7153 & 2.40 & 1.33 & 4.02 \\
\hline ICG 862 & 2.51 & 1.19 & 4.17 \\
\hline ICG 6263 & 2.58 & 0.95 & 2.90 \\
\hline ICG 5663 & 2.78 & 1.31 & 3.73 \\
\hline ICG 6888 & 2.42 & 1.51 & 3.74 \\
\hline ICG 6407 & 2.89 & 1.10 & 3.81 \\
\hline ICG 513 & 3.00 & 0.86 & 2.84 \\
\hline ICG 7181 & 3.06 & 1.09 & 3.39 \\
\hline ICG 332 & 3.09 & 1.45 & 3.52 \\
\hline ICG 4750 & 3.17 & 1.47 & 4.02 \\
\hline ICG 8285 & 3.39 & 1.32 & 3.30 \\
\hline ICG 9666 & 3.60 & 1.27 & 4.38 \\
\hline ICG 6201 & 3.82 & 1.41 & 3.97 \\
\hline ICG 721 & 3.87 & 1.01 & 3.31 \\
\hline ICG 12697 & 3.96 & 1.19 & 3.37 \\
\hline ICG 1142 & 3.95 & 0.88 & 3.19 \\
\hline ICG 1711 & 4.44 & 1.13 & 2.91 \\
\hline ICG 6654 & 4.46 & 1.03 & 2.71 \\
\hline ICG 4543 & 4.61 & 1.39 & 3.75 \\
\hline ICG 532 & 4.63 & 1.04 & 3.24 \\
\hline ICG 4670 & 4.83 & 1.49 & 3.83 \\
\hline ICG 11515 & 5.11 & 1.11 & 3.22 \\
\hline ICG 9157 & 5.33 & 1.46 & 2.72 \\
\hline ICG 6375 & 5.58 & 1.33 & 3.17 \\
\hline ICG 81 & 5.78 & 1.70 & 4.03 \\
\hline ICG 3775 & 6.22 & 0.91 & 3.34 \\
\hline ICG 12988 & 10.34 & 1.78 & 4.11 \\
\hline $55-437$ & 5.69 & 1.68 & 3.62 \\
\hline JL 24 & 861.9 & 1.37 & 3.17 \\
\hline LSD (5 \%) & 37.31 & 0.33 & 0.79 \\
\hline $\operatorname{SEm}( \pm)$ & 13.42 & 0.119 & 0.285 \\
\hline CV (\%) & 69.12 & 32.63 & 29.36 \\
\hline
\end{tabular}

six years (2008, 2009, 2010, 2011, 2012 and 2013) indicated that the mean aflatoxin levels ranged up to $5.8 \mu \mathrm{g} \mathrm{kg}^{-1}$ (ICG 13603). Lowest aflatoxin levels were recorded with ICG $1415\left(1.5 \mu \mathrm{g} \mathrm{kg}^{-1}\right)$, followed by ICG $5195\left(1.7 \mu \mathrm{g} \mathrm{kg}^{-1}\right)$, and ICG $3584\left(1.8 \mu \mathrm{g} \mathrm{kg}^{-1}\right)$. For other accessions, the aflatoxin levels were $1.9 \mathrm{\mu g} \mathrm{kg}^{-1}$ (ICG 14360), $2.0 \mu \mathrm{g} \mathrm{kg}^{-1}$ (ICG 6703), and $3.1 \mu \mathrm{g} \mathrm{kg}^{-1}$ (ICG 6888). The resistant check recorded aflatoxin levels of $5.3 \mu \mathrm{g} \mathrm{kg}^{-1}$, whereas the susceptible check recorded $581.8 \mu \mathrm{g} \mathrm{kg}^{-1}$ (Fig 2). The mean pod yields 
Table 5 Field evaluation of selected groundnut mini core accessions for pre-harvest aflatoxin contamination at Sadore, Niger in 2012 (rainy season)

\begin{tabular}{llll}
\hline Accession & $\begin{array}{l}\text { Aflatoxin } \\
\text { levels* }\left(\mu \mathrm{g} \mathrm{kg}^{-1}\right)\end{array}$ & $\begin{array}{l}\text { \% Kernel } \\
\text { A. flavus infection }\end{array}$ & $\begin{array}{l}\text { Pod yield } \\
\left(\mathrm{t} \mathrm{ha}^{-1}\right)\end{array}$ \\
\hline ICG 13603 & 0.00 & $1.54(4.63)$ & 1.98 \\
ICG 1415 & 0.42 & $1.29(3.80)$ & 2.22 \\
ICG 14630 & 0.00 & $2.0(6.24)$ & 1.39 \\
ICG 3584 & 0.30 & $1.76(5.82)$ & 1.92 \\
ICG 5195 & 0.54 & $1.76(5.82)$ & 1.91 \\
ICG 6703 & 0.67 & $2.23(7.25)$ & 2.02 \\
ICG 6888 & 0.86 & $2.70(7.27)$ & 1.98 \\
55-437 & 1.58 & $1.76(5.82)$ & 1.94 \\
JL 24 & 11.68 & $1.99(6.24)$ & 2.16 \\
LSD (5 \%) & 1.51 & $1.84(4.67)$ & 0.76 \\
SEm ( \pm ) & 0.52 & $0.63(1.59)$ & 0.23 \\
CV (\%) & 50.2 & $99.49(76.81)$ & 31.39 \\
\hline 55 & &
\end{tabular}

55-437 was the resistant check and JL 24 was the susceptible check

Values in parentheses are angular transformed values

$\%$ A. flavus infection is enumerated at harvest using standard protocols

*significant at $5 \%$ level

ranged from 1.6 to $2.2 \mathrm{tha}^{-1}$ for these seven accessions. The highest pod yields were recorded with ICG 3584

Table 6 Field evaluation of selected groundnut mini core accessions for pre-harvest aflatoxin contamination at Sadore, Niger in 2013 (rainy season)

\begin{tabular}{lll}
\hline Accession & Aflatoxin levels* $\left(\mu \mathrm{g} \mathrm{kg}^{-1}\right)$ & Pod yield $\left(\mathrm{t} \mathrm{ha}^{-1}\right)$ \\
\hline ICG 13603 & 1.0 & 4.6 \\
ICG 1415 & 1.0 & 4.1 \\
ICG 14630 & 2.9 & 3.5 \\
ICG 3584 & 1.7 & 4.2 \\
ICG 5195 & 1.8 & 3.8 \\
ICG 6703 & 2.2 & 3.7 \\
ICG 6888 & 0.2 & 3.9 \\
55-437 & 5.5 & 3.9 \\
JL 24 & 40.0 & 4.5 \\
LSD (5 \%) & 1.46 & 0.88 \\
SEm ( \pm ) & 0.50 & 0.30 \\
CV (\%) & 13.88 & 17.12 \\
\hline
\end{tabular}

55-437 was the resistant check and JL 24 was the susceptible check

*significant at $5 \%$ level
(2.2 $\mathrm{t} \mathrm{ha}^{-1}$ ), followed by ICG 6888 and ICG 13603 $\left(2.0 \mathrm{t} \mathrm{ha}^{-1}\right)$. ICGs 1415 and 6703 have recorded pod yields up to $1.9 \mathrm{t} \mathrm{ha}^{-1}$, whereas ICG 5195 and ICG 14630 recorded 1.7 and $1.6 \mathrm{t} \mathrm{ha}^{-1}$, respectively. Pod yields in resistant and susceptible checks were about 2.1 and $2.0 \mathrm{t} \mathrm{ha}^{-1}$ respectively. Haulm yields for the accessions ranged from 3.4 to $4.2 \mathrm{t} \mathrm{ha}^{-1}$ (Fig 3).

\section{Discussion}

Genetic resources make an important contribution to crop improvement programs. Hence screening of various germplasm sets, such as core and mini core collection accessions, is important for the identification of resistant sources. Previous researchers have demonstrated that valuable genes in germplasm collections can be effectively identified by using a core or mini core collection (Anderson et al. 1996a; Franke et al. 1999; Holbrook and Anderson 1995; Holbrook et al. 2000a; Isleib et al. 1995). Mini core germplasm accessions have been widely screened in several crops, including groundnut, for identifying resistant sources to different biotic (Kusuma et al. 2007) and abiotic stresses (Vadez et al. 2007). As per the previous documentation on the ICRISAT groundnut mini core collection, 28 accessions were resistant to abiotic stresses, 30 accessions were resistant to biotic stresses, 18 accessions were agronomically desirable but susceptible to different stresses, and 16 accessions were nutrient dense (Upadhyaya et al. 2014). For example, ICG 8760 and ICG 3787 were reported to be resistant to late leaf spot and rust diseases in India (Kusuma et al. 2007). Similarly, for Sclerotinia blight disease of groundnut, 67 new sources of resistance from ICRISAT mini core accessions were identified using a molecular marker (Chamberlin and Melouk 2011).

In our present study, varied reactions to pre-harvest aflatoxin contamination were observed in the ICRISAT groundnut mini core accessions during 2008 and 2009. For example, two accessions below $4 \mu \mathrm{g} \mathrm{kg}^{-1}$ were observed in 2008, whereas about 20 accessions in the similar range were observed in 2009. This trend was also observed in other aflatoxin ranges of accessions during both the years. A more reliable data for assessing the overall performance of ICRISAT groundnut mini core collection against pre-harvest aflatoxin contamination is the mean data of both 2008 and 2009 as given in Table 2. Four accessions accumulated aflatoxins up to $4 \mu \mathrm{g} \mathrm{kg}^{-1}$, which is in accordance with the European 
Fig. 2 Performance of a few groundnut mini core accessions showing resistance to pre-harvest aflatoxin contamination as evaluated during the rainy seasons of 2008 to 2013 at Sadore, Niger. 55-437 was the resistant check. JL 24 was used as a susceptible check with an aflatoxin content of $581.8 \mu \mathrm{g} \mathrm{kg}^{-1}$. Aflatoxin levels were estimated at harvest and values are the means of six years

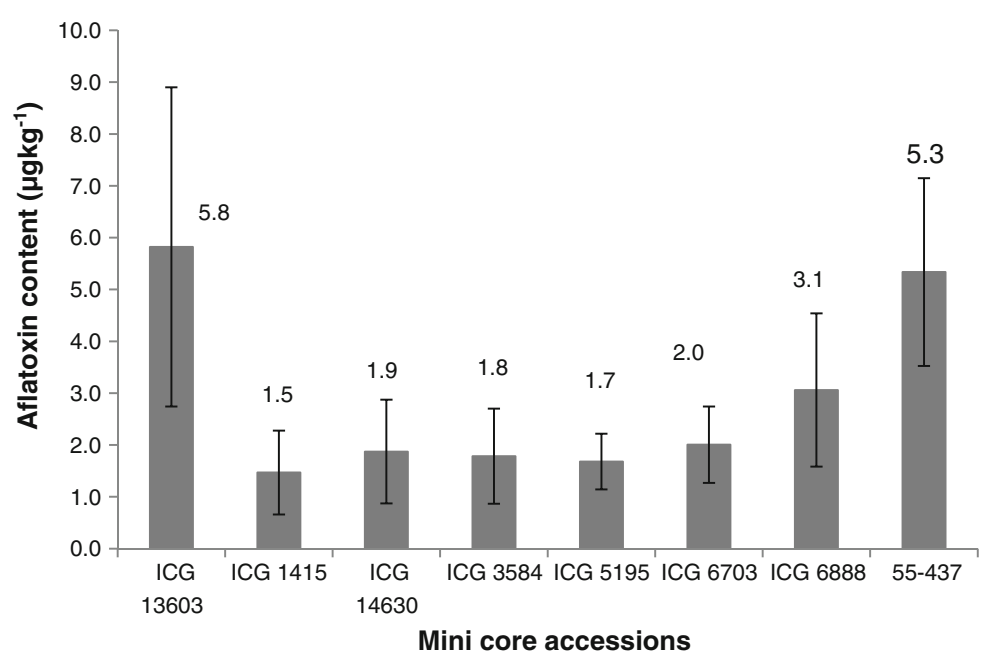

55-437 was the resistant check JL 24 was used as a susceptible check with an aflatoxin content of $581.8 \mu \mathrm{g} \mathrm{kg}^{-1}$ Aflatoxin levels were estimated at harvest and values are the means of six years
Commission standards (of total aflatoxins) for human consumption (Wilson and Otsuki 2001). Similarly, 50 accessions were within the limits stated by the Kenya Bureau of Standards, $\left(10 \mu \mathrm{g} \mathrm{kg}^{-1}\right.$ of total aflatoxins $)$ and Nigeria. A total of 66 accessions had aflatoxin level within the permissible limits $\left(15 \mu \mathrm{g} \mathrm{kg}^{-1}\right.$ of total aflatoxins) of countries such as South Africa, Australia, New Zealand, Canada, and Gulf Cooperation Council (GCC) countries like Saudi Arabia, USE, Kuwait, Bahrain, Oman, Yemen and Qatar. Similarly, 75 accessions had toxin level within the limits of United States Food and Drug Administration (FDA) safety limits $\left(20 \mu \mathrm{g} \mathrm{kg}^{-1}\right)$. Overall, 89 of the groundnut mini core accessions have met the limits set by India $\left(30 \mu \mathrm{g} \mathrm{kg}^{-1}\right)$. The rest of the accessions were with aflatoxin levels of $>30 \mu \mathrm{g} \mathrm{kg}^{-1}$. In addition, the analysis of the 34 selected accessions from the 2008-2011 field studies indicated that 23 accessions were within aflatoxin limits of $4 \mathrm{\mu g} \mathrm{kg}^{-1}$ (European Commission Standards). Overall, all the accessions have met the
Fig. 3 Pod and haulm yields of certain groundnut mini core accessions evaluated for preharvest aflatoxin contamination during the years 2008 to 2013 at Sadore, Niger. 55-437 was the resistant check and JL 24 was the susceptible check. Values are the means of six years

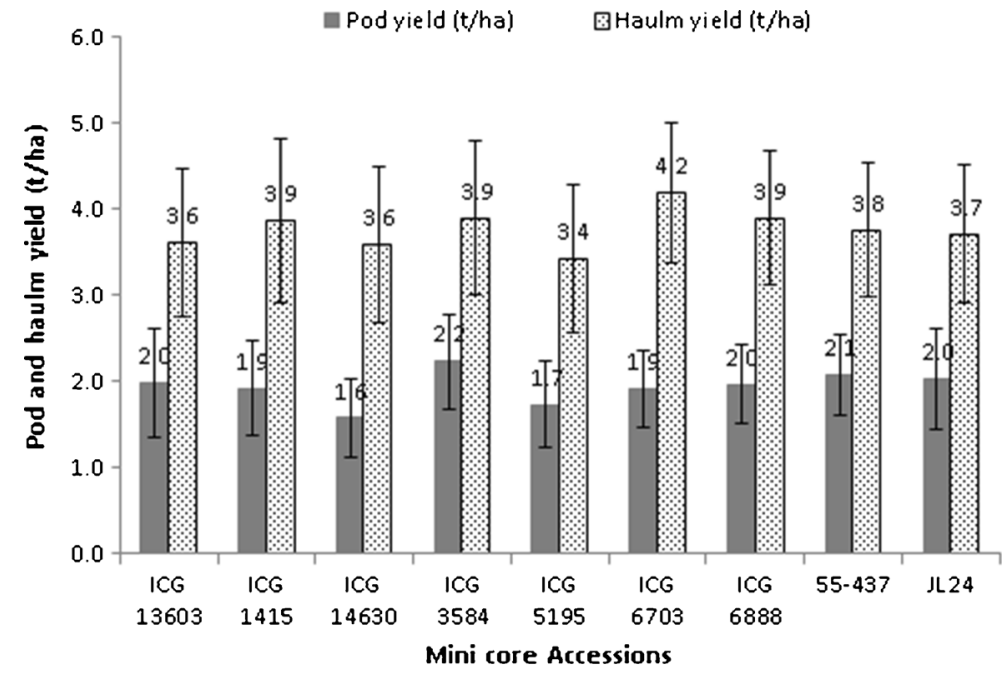

55-437 was the resistant check and JL 24 was the susceptible check Values are the means of six years 
allowable aflatoxin limits set by Kenya and Nigeria. Further, the final screening of seven best accessions (ICGs 13,603, 1415, 14,630, 3584, 5195, 6703 and 6888 ) in 2012 and 2013 indicated that pre-harvest aflatoxin contamination is $<4 \mu \mathrm{g} \mathrm{kg}^{-1}$, which is in accordance with the limits of European Commission (Tables 5 and 6). Further, the kernel infection by A. flavus for these accessions was up to $2.70 \%$ in 2012 (Table 5). However, in African countries, the legislation on aflatoxin limits are restricted only to the export crops and thus, there is a significant risk of rural poor being exposed to aflatoxins constantly with serious health impacts (Wagacha and Muthomi 2008).

Aflatoxin production in groundnut is significantly influenced by environmental parameters such as temperature and soil moisture. Due to high $\mathrm{G} x \mathrm{E}$ interaction effects, inconsistencies among genotypes offering resistance to aflatoxins have been reported under different climatic conditions (Anderson et al. 1995, 1996b; Holbrook et al. 1994). For example, drought intensity enhances aflatoxin accumulation in groundnut (Hamidou et al. 2014). Earlier studies have established that severe drought promoted growth and persistence of A. flavus population in soils, thereby resulting in high aflatoxin levels in crops (Arunyanark et al. 2010). Drought tolerant genotypes have been also reported to have tolerance to aflatoxin contamination (Holbrook et al. 2000b; Girdthai et al. 2010). For selection of resistance sources under field conditions, Niger was selected because it is one of the hottest countries in the WCA region. High temperatures and drought during the end of crop season (October/November) in Sadore, Niger, are conducive for pre-harvest aflatoxin contamination. Another reason for selecting the experimental site at Niger is that the chances of A. flavus infection at field level and aflatoxin contamination are high, even when the stress periods are short (Craufurd et al. 2006). This resulted in sufficient mold pressure on accessions during field experimentation. In our studies, the aflatoxin contamination for seven elite accessions was found to be negatively correlated with rainfall during the crop season $(r=-0.46)$. In addition, there were no rains during November, thus, creating drought which favored aflatoxin contamination. Medina et al. (2014) reported that environmental factors such as temperature and water stress have significantly influenced structural and regulatory aflatoxin biosynthetic genes. In view of the high $\mathrm{G} \times \mathrm{E}$ interactions pertaining to aflatoxin resistance in groundnut, multi-location testing of accessions under varied climatic conditions was considered to be important.

Field research at ICRISAT, Sadore, Niger has significantly contributed to the understanding of aflatoxin resistance in groundnut. Several years of field studies with groundnut mini core germplasm accessions at this site allowed the identification of significantly higher levels of resistance. In our present study, we have identified seven mini core accessions, ICGs 13,603, 1415, 14,630, 3584, 5195, 6703 and 6888, as unique with consistently low levels of pre-harvest aflatoxin contamination. ICG 13603 (Origin: Indonesia), ICG 1415 (Origin: Senegal), ICG 14630 (Origin: Brazil), ICG 3584 (Origin: India), ICG 5195 (Origin: Sudan), and ICG 6888 (Origin: Brazil) belonged to Arachis hypogaea sub sp. fastigiata. ICG 6703 (Origin: Paraguay) belonged to Arachis hypogaea sub Sp. hypogaea. These seven accessions were considered to be good candidates for a better understanding of the resistant mechanisms as well as breeding for aflatoxin resistance. However, multi-location, multienvironmental testing of these seven accessions is desirable under different climatic conditions. This is because such testing will further enhance the knowledge on the uniformity and stability of resistance of these accessions to aflatoxin contamination. Moreover, these accessions can be incorporated for field research by National Agricultural Research Systems (NARS) partners of ICRISAT in their breeding programs. While our efforts continue to identify and develop even superior aflatoxin resistance lines in groundnut, there is a need to screen these accessions in Asia, North America, South America and other African regions prior to incorporating them into groundnut breeding programs.

Acknowledgments We are thankful to CGIAR Consortium for the partial financial support rendered through CGIAR Research Program on Grain Legumes. ICRISAT is a member of the CGIAR Consortium.

\section{References}

Anderson, W. F., Holbrook, C. C., \& Culbreath, A. K. (1996a). Screening of the peanut core collection for resistance to tomato spotted wilt virus. Peanut Science, 23, 57-61.

Anderson, W. F., Holbrook, C. C., \& Wilson, D. M. (1996b). Development of greenhouse screening for resistance to Aspergillus parasiticus infection and pre-harvest aflatoxin contamination in peanut. Mycopathologia, 135, 115-118. 
Anderson, W. F., Holbrook, C. C., Wilson, D. M., \& Matheron, M. E. (1995). Evaluation of pre harvest aflatoxin contamination in several potentially resistant peanut genotypes. Peanut Science, 22, 29-32.

Arunyanark, A., Jogloy, S., Wongkaew, S., Akksaeng, C., Vorasoot, N., Kesmala, T., \& Patanothai, A. (2010). Heritability of aflatoxin resistance traits and correlation with drought tolerance traits in peanut. Field Crops Research, 117, 258-264.

Barro, N., Ouattara, C. A., Nikiema, P. A., Ouattara, A. S., \& Traore, A. S. (2002). Microbial quality assessment of some street food widely consumed in Ouagadougou, Burkina Faso. Santé, 12, 369-374.

Chamberlin, K. D., \& Melouk, H. A. (2011). Screening of the ICRISAT mini-core collection for possible Sclerotinia blight resistance and oleic acid composition. Proceedings of the American Peanut Research and Education Society, 43, 4849.

Craufurd, P. Q., Prasad, P. V. V., Waliyar, F., \& Taheri, A. (2006). Drought, pod yield, pre-harvest Aspergillus infection and aflatoxin contamination on peanut in Niger. Field Crops Research, 98, 20-29.

Franke, M. D., Brennemen, T. B., \& Holbrook, C. C. (1999). Identification of resistance to Rhizoctonia limb rot in a core collection of peanut germplasm. Plant Disease, 83, 944-948.

Girdthai, T., Jogloy, S., Vorasoot, N., Akkasaeng, C., Wongkaew, S., Holbrook, C. C., et al. (2010). Associations between physiological traits for drought tolerance and aflatoxin contamination in peanut genotypes under terminal drought. Plant Breeding, 129, 693-699.

Guo, B., Yu, J., Holbrook Jr., C., Cleveland, T., Nierman, W. C., \& Scully, B. (2009). Strategies in prevention of pre-harvest aflatoxin contamination in peanuts: aflatoxin biosynthesis, genetics and genomics. Peanut Science, 36, 11-20.

Hamidou, F., Rathore, A., Waliyar, F., \& Vadez, V. (2014). Although drought intensity increases aflatoxin contamination, drought tolerance does not lead to less aflatoxin contamination. Field Crops Research, 156, 103-110.

Hell, K., \& Mutegi, C. (2011). Aflatoxin control and prevention strategies in key crops of sub-Saharan Africa. African Journal of Microbiology Research, 55, 459-466.

Holbrook, C. C., \& Anderson, W. F. (1995). Evaluation of a core collection to identify resistance to late leaf spot in peanut. Crop Science, 35, 1700-1702.

Holbrook, C. C., Anderson, W. F., \& Pittman, R. N. (1993). Selection of a core collection from the U.S. germplasm collection of peanut. Crop Science, 33, 859-861.

Holbrook, C. C., Guo, B. Z., Wilson, D. M., \& Timper, P. (2009). The U.S. breeding program to develop peanut with drought tolerance and reduced aflatoxin contamination. Peanut Science, 36, 50-53.

Holbrook, C. C., Kvien, C. K., Rucker, K. S., Wilson, D. M., Hook, J. E., \& Matheron, M. E. (2000b). Pre harvest aflatoxin contamination in drought-tolerant and drought-intolerant peanut genotypes. Peanut Science, 27, 45-48.

Holbrook, C. C., Matheron, M. E., Wilson, D. W., Anderson, W. F., Will, M. E., \& Noden, A. J. (1994). Development of a large-scale field screening system for resistance to pre harvest aflatoxin contamination. Peanut Science, 21, 20-22.

Holbrook, C. C., Stephenson, M. G., \& Johnson, A. W. (2000a). Level and geographical distribution of resistance to
Meloidogyne arenaria in the U.S. peanut germplasm collection. Crop Science, 40, 1168-1171.

ICRISAT. (2009). ICRISAT archival report. Sustaining biodiversity of sorghum, pearl millet, small millets, groundnut, pigeonpea and chickpea for current and future generations. ICRISAT, Patancheru, India. http://www.icrisat.org/icrisatarchival-reports.htm.

Isleib, T. G., Beute, M. K., Rice, P. W., \& Hollowell, J. E. (1995). Screening the core collection for resistance to Cylindrocladium black rot and early leaf spot. Proceedings of the American Peanut Research And Education Society, 27, 25.

Kisyombe, C. T., Beute, M. K., \& Payne, G. A. (1985). Field evaluation of peanut genotypes for resistance to infection by Aspergillus parasiticus. Peanut Science, 12, 12-17.

Knauft, D. A., \& Gorbet, D. W. (1989). Genetic diversity among peanut cultivars. Crop Science, 29, 1417-1422.

Kusuma, V. P., Yugandhar, G., Ajay, B. C., Gowda, M. V. C., \& Upadhyaya, H. D. (2007). Identification of sources of multiple disease resistance in groundnut (Arachis hypogaea L.) mini core. In: Proceedings of the National Seminar "Challenges before India", Hyderabad, India. 29-31 Jan. 2007. Indian Society Of Oilseeds Research, rajendranagar, Hyderabad, India. P. 31-32.

Liao, B., Zhuang, W., Tang, R., Zhang, X., Shan, S., Jiang, H., et al. (2009). Peanut aflatoxin and genomics research in China: progress and perspectives. Peanut Science, 36, 21-28.

Medina, A., Rodriguez, A., \& Magan, N. (2014). Effect of climate change on Aspergillus flavus and aflatoxin $\mathrm{B}_{1}$ production. Frontiers in Microbiology, 5, 1-7.

Mehan, V. K. (1989). Screening groundnuts for resistance to seed invasion by Aspergillus flavus and to aflatoxin production (pp. 323-334). In D. McDonald, \& V. K. Mehan (Eds.), Aflatoxin contamination of groundnut. proc. int. workshop, 6-9 Oct. 1987. ICRISAT Center, India. patancheru, A.P. 502 3234, India International Crops Research Institute for the Semi-Arid Tropics.

Monyo, E. S., Njoroge, S. M. C., Coe, R., Osiru, M., Madinda, F., Waliyar, F., et al. (2012). Occurrence and distribution of aflatoxin contamination in groundnuts (Arachis hypogaea L) and population density of Aflatoxigenic Aspergilli in Malawi. Crop Protection, 42, 149-155.

Nigam, S. N., Waliyar, F., Aruna, R., Reddy, S. V., Lava Kumar, P., Craufurd, P. Q., et al. (2009). Breeding peanut for resistance to aflatoxin contamination at ICRISAT. Peanut Science, 36, 42-49.

Raper, K. B., \& Fennel, D. I. (1965). The genus Aspergillus. Williams \& Wilkins, Baltimore.

Reddy, S. V., Kiran Mayi, D., Uma Reddy, M., Thirumala Devi, K., \& Reddy, D. V. R. (2001). Aflatoxin $B_{1}$ in different grades of chillies (Capsicum annum) as determined by indirect competitive-ELISA. Food Additives \& Contaminants, $18,553-558$.

Sivakumar, M.V.K. (1986). Climate of Niamey. Progress Report no. 1. B.P. 12404, Niamey, Niger: ICRISAT Sahelian Center.

Thakur, R. P., Rao, V. P., Reddy, S. V., \& Ferguson, M. (2000). Evaluation of wild Arachis germplasm accessions for in vitro seed colonization and aflatoxin production by Aspergillus flavus. International Arachis Newsletter, 20, 44-46.

Upadhyaya, H. D., Dwivedi, S. L., Vadez, V., Hamidou, F., Singh, S., Varshney, R. K., et al. (2014). Multiple resistant and 
nutritionally dense germplasm identified from mini core collection in peanut. Crop Science, 54, 679-693.

Upadhyaya, H. D., Bramel, P. J., Ortiz, R., \& Singh, S. (2002b). Developing a mini core of peanut for utilization of genetic resources. Crop Science, 42, 2150-2156.

Upadhyaya, H. D., Nigam, S.N., Mehan, V.K., \& Lenne, J.M. (1997). Aflatoxin contamination of groundnut - prospects of a genetic solution through conventional breeding, (pp. 8185). In Aflatoxin Contamination Problems in Groundnut in Asia: Proceedings of the First Working Group Meeting, 2729 May 1996, Ministry of Agriculture and Rural Development, Hanoi, Vietnam (V.K. Mehan and C.LL. Gowda eds.). Patancheru 502 324, Andhra Pradesh, India: International Crops Research Institute for the Semi-Arid Tropics.

Upadhyaya, H. D., Nigam, S. N., Mehan, V. K., Reddy, A. G. S., \& Yellaiah, N. (2001). Registration of Aspergillus flavus seed infection resistant peanut germplasm ICGV 91278, ICGV 91283, and ICGV 91284. Crop Science, 41, 559-600.

Upadhyaya, H. D., Nigam, S. N., \& Thakur, R. P. (2002a). Genetic enhancement for resistance to aflatoxin contamination in groundnut. In F. Waliyar, \& M. Adomou (Eds.), Summary proceedings of the 7th ICRISAT regional groundnut meeting for Western and Central Africa, (6-8 December 2000, Cotonou, Benin) (pp. 29-36). Patancheru, India: ICRISAT.

Upadhyaya, H. D., Nigam, S. N., \& Waliyar, F. (2004). Aflatoxin contamination of groundnut: conventional breeding for resistance. In J. Robens (Ed.), Proceedings of the 3rd fungal genomics, 4th fumonisin, and 16th aflatoxin elimination workshops (13-15 October 2003, Savannah, Georgia, USA) (p. 55). ARS, Beltsville, Maryland: USDA.

Upadhyaya, H. D., Ortiz, R., Bramel, P. J., \& Singh, S. (2003). Development of a groundnut core collection using taxonomical, geographical and morphological descriptors. Genetic Resources and Crop Evolution, 50, 139-148.

Upadhyaya, H. D., Yadav, D., Dronavalli, N., Gowda, C. L. L., \& Singh, S. (2010). Mini core germplasm collections for infusing genetic diversity in plant breeding programs. Electronic Journal of Plant Breeding, 1, 1294-1309.

Utomo, S.D., Anderson, W.F., Wynne, J.C., Beute, M.K., Hagler, Jr. W.M., \& Payne, G.A. (1990). Estimates of heritability and correlation among three mechanisms of resistance to Aspergillus parasiticus in peanut. Proc. Amer. Peanut Res. and Educ. Soc. 22:26. (abstr.)

Vadez, V., Krishnamurthy, L., Serraj, R., Gaur, P. M., Upadhyaya, H. D., Hoisington, D. A., et al. (2007). Large variation in salinity tolerance in chickpea is explained by differences in sensitivity at reproductive stages. Field Crops Research, 104, 123-129.

Wagacha, J. M., \& Muthomi, J. W. (2008). Mycotoxin problem in Africa: current status, implications to food safety and health and possible management strategies. International Journal of Food Microbiology, 124, 1-12.

Waliyar, F., \& Bockelee-Morvan, A. (1989). Aflatoxin contamination of groundnut: ICRISAT (International Crops Research Institute for the Semi-Arid Tropics). Proceedings of the International Workshop, 6-9 Oct 1987, ICRISAT Center, Patancheru, A.P. 502324, India.

Waliyar, F., Ba, A., Hassan, H., Bonkongou, S., \& Bosc, J. P. (1994). Sources of resistance to Aspergillus flavus and aflatoxin contamination in groundnut genotypes in West Africa. Plant Disease, 78, 704-708.

Waliyar, F., Kumar, P. L., Ntare, B. R., Diarra, B., \& Kodio, O. (2008). Pre and post-harvest management of aflatoxin contamination in peanuts. In J. F. Leslie et al. (Eds.), Mycotoxins: detection methods, management, public health and agricultural trade. Wallingford: CABI.

Waliyar, F., Traore, D., Fatondji, D., \& Ntare, B. R. (2003). Effect of irrigation interval, planting date and cultivar on Aspergillus flavus and aflatoxin contamination of peanut in a sandy soil of Niger. Peanut Science, 30, 79-84.

Waliyar, F., Umeh, V. C., Traore, A., Osiru, M., Ntare, B. R., Diarra, B., et al. (2015b). Prevalence and distribution of aflatoxin contamination in groundnut (Arachis hypogaea L.) in Mali, West Africa. Crop Protection, 70, 1-7.

Waliyar, F., Osiru, M., Ntare, B. R., Vijay Krishna Kumar, K., Sudini, H., Traore, A., et al. (2015a). Post-harvest management of aflatoxin contamination in groundnut. World Mycotoxin Journal, 8(2), 245-252.

West, L. T., Wilding, L. P., Landeck, J. K., \& Calhoun, F. G. (1984). Soil survey of the ICRISAT Sahelian Centre, Niger, West Africa. Soil and Crop Science Department. College Station, TX, USA and ICRISAT, Patancheru, India: Texas A \& M University.

Wild, C. P., \& Gong, Y. Y. (2010). Mycotoxins and human disease: a largely ignored global health issue. Carcinogenesis, 31, 7182.

Williams, J. H., Phillips, T. D., Jolly, P. E., Stiles, J. K., Jolly, C. M., \& Aggarwal, D. (2004). Human aflatoxicosis in developing countries: a review of toxicology, exposure, potential health consequences and interventions. American Journal of Clinical Nutrition, 80, 1106-1122.

Wilson, J. S., \& Otsuki, T. (2001). Global trade and food safety: winners and losers in a fragmented system. In World Bank working paper 2689 (October 2001). Washington DC: USA.

Yugandhar, G. (2005). Evaluation of mini core set of germplasm in groundnut (Arachis hypogaea L.), M. Dharwad, India: Sc. thesis. University of Agricultural Sciences.

Zambettakis, C., Waliyar, F., Bockelee-Morvan, \& de Pins, O. (1981). Results of four years of research on resistance of groundnut varieties to Aspergillus flavus. Oleagineux, 36, 377-385. 